TOMASZ WESOŁOWSKI (Białystok)

\title{
ZA KULISAMI PROPAGANDY NIEMIECKIEJ \\ W KAMPANII WRZEŚNIOWEJ - PIERWSI KAWALEROWIE KRZYŻA RYCERSKIEGO PODCZAS WALK O WARSZAWSKI FORT II (26 WRZEŚNIA 1939 R.)
}

1 września 1939 r. kanclerz Rzeszy i Głównodowodzący Wehrmachtu Adolf Hitler ustanowił nowe odznaczenia: Krzyż Żelazny oraz Krzyż Rycerski Żelaznego Krzyża. Pierwsze z odznaczeń - Krzyż Żelazny (niem. Eisernes Kreuz), nadawane w dwóch klasach, było wznowieniem odznaczenia wprowadzonego po raz pierwszy w 1813 r. i wznawianego już dwukrotnie w latach 1870-1871 oraz 1914-1918. Podczas II wojny światowej nadano łącznie około 5 mln Krzyży Żelaznych obu klas. Odznaczeniem o wiele bardziej prestiżowym był zatem Krzyż Rycerski Żelaznego Krzyża (niem. Ritterkreuz des Eisernen Kreuzes), ustanowiony w miejsce funkcjonującego od 1813 r. orderu Pour le Merite ${ }^{1}$. W okresie od października 1939 r. do kwietnia 1945 r. wręczono łącznie około 7200 orderów Krzyża Rycerskiego. Od 1940 r. wprowadzano stopniowo dodatkowe wyróżnienia, w postaci liści dębowych (niem. Eichenlaub, 853 nadania), mieczy (niem. Schwerter, 150 nadań) oraz diamentów (niem. Brillanten, 27 nadań) do Krzyża Rycerskiego. W drodze wyjątku nadano złote liście dębowe (w pojedynczym egzemplarzu dla Obersta Hansa-Ulricha Rudela) oraz Krzyż Wielki (w pojedynczym egzemplarzu dla Reichsmarschalla Hermanna Göringa). 204 osobom wręczono ponadto Krzyż Rycerski Wojennego Krzyża Zasługi (niem. Ritterkreuz des Kriegsverdienstkreuzes), będący odmianą odznaczenia, przeznaczoną dla osób cywilnych ${ }^{2}$.

1 Verordnung über die Erneuerung des Eisernen Kreuzes vom 1. September 1939, w: G. Seemen, Die Ritterkreuzträger 1939-1945, Bad Nauheim 1955, s. 9; C. Ailsby, Combat medals of the Third Reich, Wellingborough 1987, s. 45-58.

2 G. Seemen, op. cit., s. 9. 
Dekoracja pierwszych oficerów, odznaczonych Krzyżami Rycerskimi, miała miejsce 27 października 1939 r. Wyróżniona została wówczas grupa kilkunastu uczestniczących w kampanii polskiej generałów, jeden oficer starszy - Oberst August Schmidt, a także dwaj oficerowie młodsi - Oberleutnant Dietrich Steinhardt oraz Leutnant Josef Stolz. To właśnie wnioski o odznaczenie dwóch ostatnich oficerów były pierwszymi, pozytywnie rozpatrzonymi przez Naczelne Dowództwo Wehrmachtu. Obaj oficerowie, służący w 51 pp dolnośląskiej 18 DP, wyróżnili się podczas walk o Warszawę 26 września 1939 r., a więc w końcowym etapie kampanii polskiej. Napływające wcześniej wnioski, pozytywnie opiniowane przez dowództwa korpusów, armii i grup wojsk lądowych, były przez OKW konsekwentnie odrzucane. Co prawda, planowano odznaczenie Krzyżami Rycerskimi, już po zakończeniu kampanii, grupy najwyższych rangą oficerów sztabowych i dowódców związków operacyjnych, jednak organa propagandowe nalegały na uhonorowanie również kilku oficerów młodszych, wyróżniających się na polu walki.

O nadaniu Krzyży Rycerskich Oberleutnantowi D. Steinhardtowi i Leutnantowi J. Stolzowi niemiecki aparat propagandowy poinformował społeczeństwo niemal miesiąc przed uroczystym wręczeniem odznaczeń, w związku z czym to właśnie tych dwóch oficerów 51 pp zwykło uważać się za pierwszych kawalerów odznaczenia. Obaj oficerowie byli ludźmi stosunkowo młodymi, mającymi za sobą po kilka lat służby wojskowej bez wyróżnień i zaszczytów.

Dietrich Steinhardt urodził się 6 kwietnia 1914 r. w m. Glaubitz (powiat Riesa w Saksonii). W 1932 r. jako ochotnik wstąpił do 7 pp, stacjonującego w Schweidnitz (Świdnica). 1 października 1934 r. został promowany na najniższy stopień oficerski. Awansowany do stopnia Oberleutnanta został przeniesiony do $51 \mathrm{pp}$, stacjonującego w Liegnitz (Legnica) i Bunzlau (Bolesławiec). We wrześniu 1939 r. pełnił służbę na stanowisku dowódcy 2 kompanii I batalionu $51 \mathrm{pp}^{3}$.

Josef Stolz urodził się 19 maja 1915 r. w Wiener Neustadt w Austrii jako syn dowódcy batalionu 73 pp, poległego na froncie w końcu $1914 \mathrm{r}$. 1 września 1935 r., jako tzw. ,jednoroczny ochotnik" (niem. Einjährig-Freiwilliger), wstąpił do austriackiego 5 pp. Po dokonaniu Anschlussu Austrii przez III Rzeszę, 13 marca 1938 r. został przeniesiony do niemieckiego Wehr-

3 E. Mohr, Gedenkbuch der niederschlesischen 18. Inf.-/Pz.-Gren.-Division. Friedensstandort Liegnitz, Hamburg 1998, s. 248. 
machtu. 1 września 1938 r. został promowany na najniższy. stopień oficerski, otrzymując stanowisko dowódcy plutonu w 10 kompanii III batalio$\mathrm{nu} 51 \mathrm{pp}^{4}$.

W niemieckiej prasie wojskowej, a także literaturze propagandowej, pojawił się zwyczaj publikowania artykułów opisujących czyny, za które żołnierze odznaczani byli Krzyżami Rycerskimi. Wydawano specjalne dodatki gazet, publikowano plakaty, a nawet serie kart pocztowych z podobiznami kawalerów tego orderu W późniejszych latach wojny, wraz ze stale rosnącą liczbą nadawanych odznaczeń, postacie kawalerów Krzyża Rycerskiego wyraźnie spowszedniały. W prasie i literaturze ukazywały się najczęściej skromne notki, czasem ilustrowane niewielkich rozmiarów fotografiami. Ostro kontrastowało to z publikacjami z początkowego okresu wojny - dużymi, panegirycznymi biogramami oraz całostronicowymi portretami.

Osobom dwóch pierwszych kawalerów Krzyża Rycerskiego w prasie i literaturze propagandowej poświęcono dość dużo uwagi. Publikowano biogramy, portrety, ich nazwiska pojawiały się w niemal każdej publikacji poświęconej kampanii polskiej i zdobyciu Warszawy. Dziwi jednak fakt, iż tak rozsławianym czynem obu oficerów - zdobyciem warszawskiego Fortu II nie zainteresowało się żadne $\mathrm{z}$ wojskowych czasopism fachowych, wydawanych przez Naczelne Dowództwo Wojsk Lądowych. Dość powszechną wówczas praktyką było analizowanie na ich łamach wybranych autentycznych przykładów taktycznych starć ze stoczonych kampanii, służące przede wszystkim celom szkoleniowym. Bardzo często, jako przykłady analizowanych starć, dobierano wydarzenia z udziałem kawalerów najwyższych odznaczeń, wprowadzając do szkolenia wątek propagandowy.

Zdobycie Fortu II w Warszawie, za który to czyn przyznano dwa pierwsze Krzyże Rycerskie, nadawało się do tego celu w sposób szczególny. Pomimo to $\mathrm{w}$ żadnej z publikacji fachowych aż do końca wojny nie pojawił się szczegółowy opis walk o ten fort stoczonych we wrześniu 1939 r. Wszelkie publikacje poświęcone temu tematowi były bardzo ogólnikowe i nosiły typowo propagandowy charakter. Bezcelowa byłaby zatem próba odtworzenia szczegółowego przebłtgu walk tylko na ich podstawie. Stało się to możliwe dopiero po wojnie, kiedy udostępniono, a nawet częściowo opublikowano dokumenty dotyczące działań 18 DP w walkach o Warszawę, a także wówczas, gdy pojawiły się opracowania przygotowane przez weteranów dywizji. Tym samym stało się jasne, dlaczego mimo propagandowej wrzawy wokół

4 Ibidem, s. 249. 


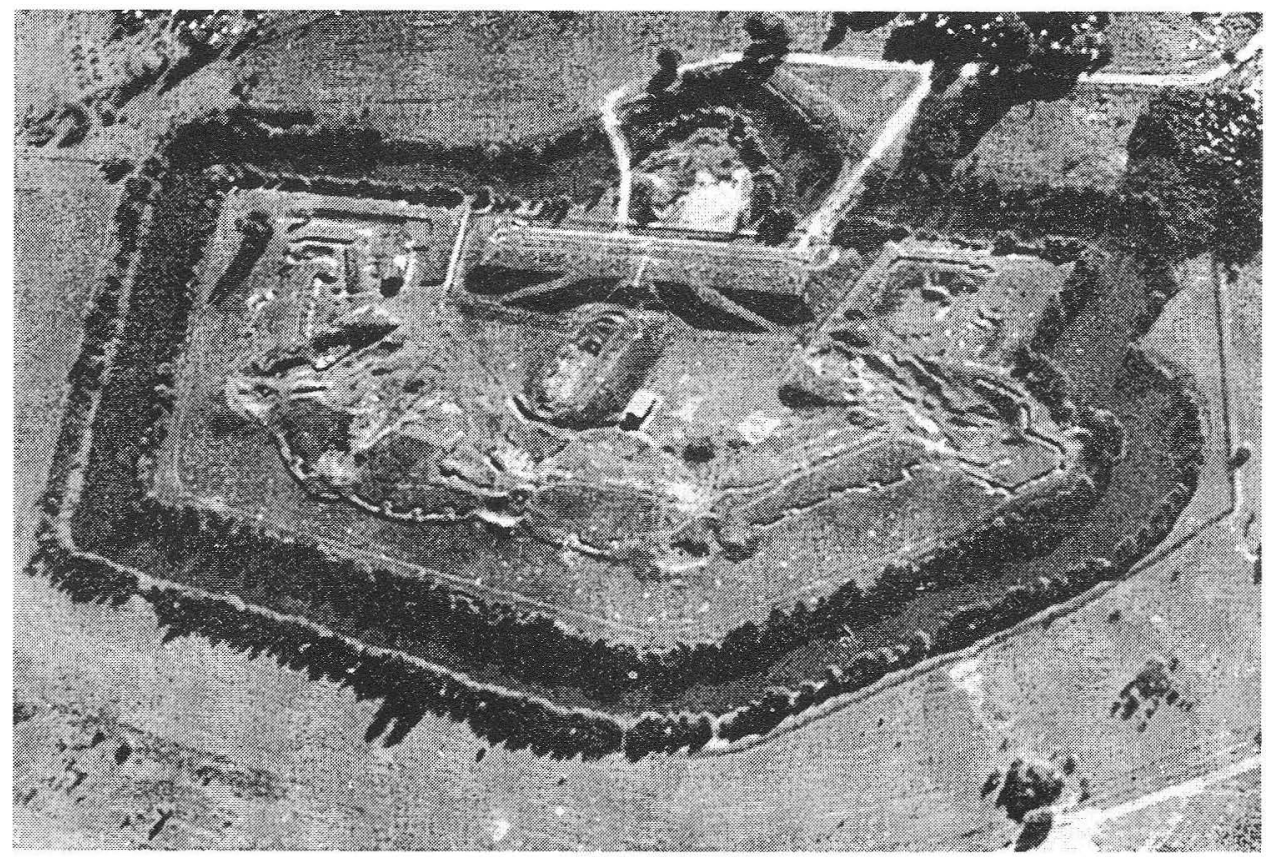

Fort II - niemiecka fotografia lotnicza z 1939 r.

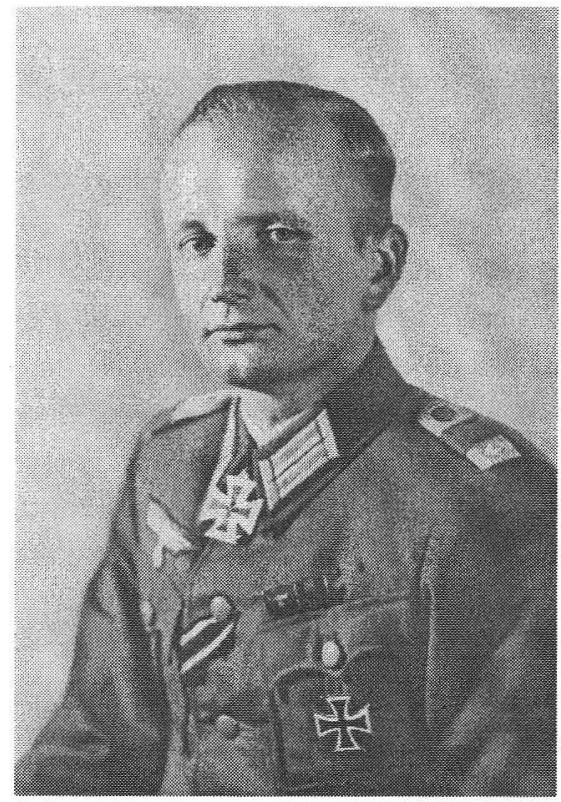

Oberleutnant Dietrich Steinhardt, dowódca 2 kompanii $51 \mathrm{pp}$

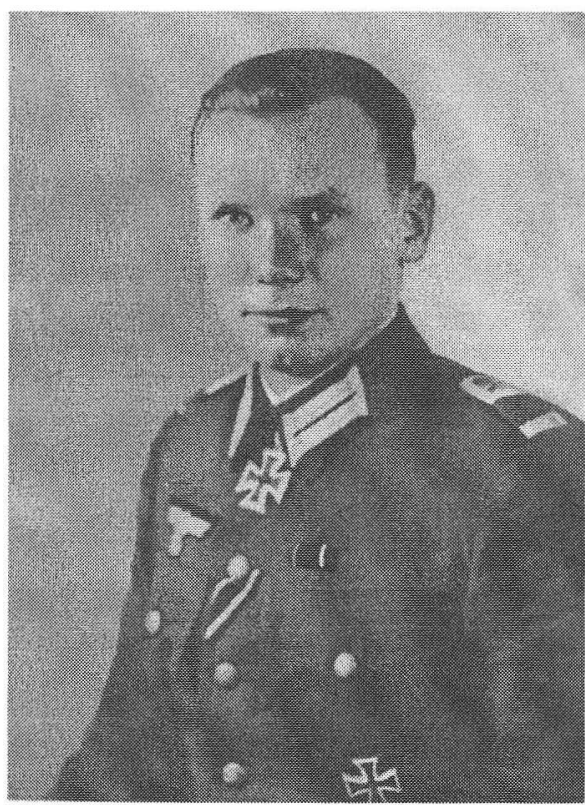

Leutnant Josef Stolz, dowódca 10 kompanii 51 pp 
osób Oberleutnanta D. Steinhardta i Leutnanta J. Stolza, Niemcom zależało na utrzymaniu w tajemnicy rzeczywistego przebiegu wydarzeń 26 września 1939 r., rozgrywających się w warszawskim Forcie II.

Fort II był jednym $z$ obiektów północno-zachodniej części pierścienia zewnętrznego rosyjskiej Twierdzy Warszawa. Dzieło wzniesiono w latach 1885-1888, w odległości około $3 \mathrm{~km}$ na zachód od wsi Chomiczówka i Wawrzyszew. Fort posiadał dwa wały oraz rów wodny. Dzieło wyróżniał niesymetryczny narys, $z$ charakterystycznie załamanym lewym barkiem, w którym umieszczono dodatkową półkaponierę. Również obronę szyi rozwiązano w nietypowy sposób, lokując na zapolu koszar kaponierę flankująca rów. Po 1892 r. fort przeszedł modernizację, polegającą na przekształceniu go w dzieło jednowałowe, przy równoczesnym wzmocnieniu betonem ceglanych sklepień. W związku z decyzją o kasacji Twierdzy Warszawa z 31 stycznia 1909 r., dzieło zostało w 1913 r. rozbrojone i częściowo ro$z_{\text {zebrane }}^{5}$. W 1918 r. Fort II wraz z przyległymi terenami o łącznej powierzchni 27 ha $1742 \mathrm{~m}^{2}$ przejęło Wojsko Polskie. Komisja badająca przydatność dzieł fortecznych określiła stan fortu jako „zaniedbany”, przyznając mu w klasyfikacji kategorię B i degradując go do roli obiektu magazynowego ${ }^{6}$. W $1927 \mathrm{r}$. fort objęto robotami publicznymi, przekazując rozbiórkę wysadzonych przez Rosjan elementów bezrobotnym, zatrudnianym przez oddział drogowy sejmiku warszawskiego ${ }^{7}$. W 1931 r. Ministerstwo Spraw Wojskowych przekazało fort Centralnej Składnicy Amunicyjnej ${ }^{8}$, która urządziła na terenie dzieła składy, funkcjonujące aż do września $1939 \mathrm{r}$.

W przygotowywanych planach obronnych Fortowi II, podobnie jak pozostałym dziełom zlikwidowanej Twierdzy Warszawa, nie przypisano żadnej roli. W dniu 4 września 1939 r. fort został na krótko obsadzony przez dwa plutony 201 kompanii asystencyjnej (d-ca por. Tadeusz Albiński). Zadaniem, urządzonego wówczas na terenie dzieła, wysuniętego ośrodka oporu Wawrzyszew była osłona ewakuacji magazynów amunicyjnych. Akcję za-

5 L. Królikowski, Twierdza Warszawa, Warszawa 2002, s. 37, 223; C. Głuszek, Twierdza Warszawa, w: Twierdze i dziatania wojenne na ziemiach polskich w czasie I wojny światowej, Białystok-Przasnysz 2000, s. 51-52.

6 Centralne Archiwum Wojskowe [dalej: CAW], Akta Dowództwa Okręgu Korpusu Nr I [dalej: DOK I], 371.1.183, Zarzad Nieruchomości Okręgowego Urzędu Budownictwa Nr 1, Wykaz obiektów fortyfikacyjnych Warszawy i okolic, styczeń $1933 \mathrm{r}$.

7 Rozbiórka fortu, „Polska Zbrojna” 1927, nr 113, s. 7.

8 CAW, DOK I, 371.1.183, Zarzad Nieruchomości.... 
kończono 7 września 1939 r., po czym fort został opuszczony ${ }^{9}$. Po południu 10 września 1939 r. fort został zajęty przez I batalion 12 zmotoryzowanego pułku strzelców niemieckiej 4 DPanc., przystępującej po nieudanej próbie zajęcia Warszawy z marszu do tworzenia tzw. „pozycji zaporowej” (niem. Sperrstellung) - linii blokady wojsk polskich skoncentrowanych w rejonie stolicy. 14 września 1939 r., w związku ze zluzowaniem pułku przez 31 DP, Fort II został opuszczony ${ }^{10}$.

Dzieło pozostawało nieobsadzone aż do 21 września 1939 r., kiedy w jego pobliże zaczęły ściągać rozbite jednostki polskie znad Bzury. W rejonie fortu znalazły się resztki 15 DP ze składu Armii „Pomorze”. Po przegrupowaniu sił dywizji wchodzący w jej skład $61 \mathrm{pp}$, a raczej jego resztki, dowodzone przez por. Hugona Blecherta, otrzymały rozkaz obsadzenia wysuniętego ośrodka oporu „Wawrzyszew”, którego trzonem miał być Fort II. Wieczorem 22 września 1939 r. 3 kompania I batalionu 61 pp (d-ca por. Tadeusz Hazler) zluzowała dotychczasową obsadę dzieła. Była to jedna $z$ dwóch zbiorczych kompanii sformowanych 21 września z rozbitków 9 DP Armii „Pomorze”, którzy zdołali przebić się do Warszawy. Kompanię por. T. Hazlera włączono do I batalionu $61 \mathrm{pp}$. Batalion zajmował odcinek o szerokości około $1 \mathrm{~km}$, od cmentarza w Wawrzyszewie Starym do Fortu II. Samo dzieło zostało obsadzone przez I pluton 3 kompanii (d-ca ppor. Stanisław Charytoniuk). Na lewo od fortu, na terenie zabudowań Wawrzyszewa Nowego, stanowiska zajął III pluton (d-ca ppor. Chodorowski), zaś na prawo II pluton (d-ca ppor. Ryszkowski). Sąsiadem kompanii na prawym skrzydle była druga zbiorcza kompania rozbitków z 9 DP (d-ca por. Kazimierz Różycki), włączona jako 9 kompania do III batalionu 61 pp, zajmująca pozycje w rejonie kościoła i cmentarza w Wawrzyszewie Nowym ${ }^{11}$.

24 września 1939 r. stanowiska na przedpolu Fortu II zaczęły zajmować oddziały niemieckiej $18 \mathrm{DP}$, przygotowującej się do szturmu generalnego na Warszawę. Dowództwo XI Korpusu Armijnego, któremu podlegała 18 DP, zdawało sobie sprawę z faktu obsadzenia przez oddziały polskie części dzieł dawnego pierścienia zewnętrznego Twierdzy Warszawa. Stąd tė̇ przed głównym uderzeniem na miasto, zaplanowanym na dzień 27 września

9 J. Janowski, Dziennik zastępcy dowódcy obrony Warszawy w 1939 roku, w: Obrona Warszawy 1939 we wspomnieniach, pod red. M. Cieplewicza i E. Kozłowskiego, Warszawa 1984, s. 151.

10 O. Schaub, Aus der Geschichte Panzer-Grenadier-Regiment 12 (SR. 12), Bergisch Gladbach 1957, s. 25-26.

11 J. Izdebski, Dzieje 9 Dywizji Piechoty 1918-1939, Warszawa 2000, s. 294-295. 
1939 r., zamierzano przeprowadzić siłami dwóch dywizji piechoty serię lokalnych natarć, mających na celu likwidację wysuniętych ośrodków oporu w fortach. 25 września 1939 r. w dzienniku działań bojowych XI KA zanotowano wytyczne na dzień następny: „18 Dyw.[izja] zajmie wypadem Fort II, otaczając umocnienia przy rozwidleniu dróg na wsch.[ód] od m. Gać od południa i przesunie pierwszą linię do Brzezin" ${ }^{12}$. Zdobycie Fortu II powierzono 51 pp (d-ca Oberst Wilhelm Bohnstedt) 18 DP. Dowództwo pułku postanowiło zdobyć fort, wykorzystu jąc element zaskoczenia. W związku z tym zdecydowano o rezygnacji $z$ wykonania przygotowania artyleryjskiego. II dywizjon 18 part. (d-ca Major von Below) otrzymał zadanie położenia w nocy z 25 na 26 września na fort jedynie ognia nękającego i przerwania go tuż przed atakiem, by nie utracić czynnika zaskoczenia. Równocześnie z siłami $51 \mathrm{pp}$ do natarcia miał ruszyć lewoskrzydłowy $30 \mathrm{pp} \mathrm{z} \mathrm{zadaniem} \mathrm{zdobycia}$ rozwidlenia dróg, położonego $1 \mathrm{~km}$ na wschód od $\mathrm{m}$. Gać ${ }^{13}$.

Do bezpośredniego natarcia na fort wyznaczono I batalion $51 \mathrm{pp}$ (d-ca Oberstleutnant Alfred Hemman), podporządkowując jego dowódcy dodatkowo 10 kompanię $51 \mathrm{pp}$, pluton lekkich dział piechoty, pluton armat przeciwpancernych, także pluton z 2 kompanii 48 zmotoryzowanego batalionu pionierów. Optymizm dowództwa pułku, co do powodzenia planowanego natarcia, utwierdził rekonesans pozycji obrońców, przeprowadzony przez pododdział rozpoznawczy pod dowództwem Unteroffiziera Kittnera z 51 pp oraz Leutnanta Schmelzera, wysuniętego obserwatora 6 baterii 18 part. Żołnierzom niemieckim udało się niepostrzeżenie dotrzeć aż na skraj rowu wodnego, a następnie bez otwierania ognia powrócić. Sporządzony przez Unteroffiziera Kittnera i Leutnanta Schmelzera meldunek o słabej obsadzie fortu uznano za wiarygodny, tym bardziej że pokrywał się z zeznaniami przesłuchiwanego w sztabie XI KA wziętego do niewoli polskiego oficera, twierdzącego iż fort obsadzony jest jedynie przez niewielką placówkę ${ }^{14}$. Kolejny rekonesans przeprowadził wieczorem osobiście dowódca I batalionu $51 \mathrm{pp}$

12 Archiwum Akt Nowych [dalej: AAN], Mikrofilmy Aleksandryjskie [dalej: MA], T-314, rolka 477, kl. 000062, Generalkommando XI. AK, Kriegstagebuch Nr 1, Eintragung 25.9.1939.

13 J. Engelmann, Lohn der Tapferkeit. Aus der Geschichte des Artillerie-Regiments 18 der 18. Infanterie-/Panzergrenadier-Division Liegnitz, Oldenburg 1989, t. I, s. 86-87, maszynopis w zbiorach Zentralbibliothek der Bundeswehr Düsseldorf.

14 18. Division Ia, Bericht über die Erstürmung des Fort II am 26.9.1939, 1.10.2939, w: W. Herrmann, Die Geschichte des Infanterie-Regiments 51 und in Teilen die der 18. Inf. Div., München 1964, s. 63-64; H. Nolte, Der Handstreich auf Werk Zwei. Zwei 51er errangen die ersten Ritterkreuze der Wehrmacht, „Alte Kameraden” 1980, nr 5, s. 18. 
Oberstleutnant A. Hemman w towarzystwie swego adiutanta Leutnanta Poeschmanna. Również on zdołał niepostrzeżenie dotrzeć na odległość $200 \mathrm{~m}$ od fosy fortu i przez pewien czas obserwować dzieło, uznając je za słabo obsadzone i stosunkowo łatwe do zdobycia.

Rekonesans utwierdził Oberstleutnanta A. Hemmana w przekonaniu, iż najwłaściwszą metodą ataku na Fort II będzie niespodziewany wypad, bez wsparcia artylerii. W związku z tym dowódca I batalionu $51 \mathrm{pp}$ podzielił atakujące siły na dwie grupy. 2 kompania (d-ca Oberleutnant D. Steinhardt) - wzmocniona plutonem pionierów (z 2 kompanii 48 batalionu pionierów), plutonem broni maszynowej i drużyną granatnika ( 4 kompanii $51 \mathrm{pp}$ ) otrzymała zadanie zajęcia fortu od strony południowo-zachodniego narożnika. Natomiast 3 kompanii (d-ca Leutnant Hildebrandt) powierzono zadanie wykonania uderzenia na fort na wysokości wschodniego skraju, utrzymywania styczności z sąsiednim 30 pp i osłaniania natarcia 2 kompanii od północnego-wschodu. W tym czasie 1 kompania (d-ca Leutnant Suckert) miała pozostać na pozycjach wy jściowych w charakterze odwodu ${ }^{15}$.

Przed godziną 4.30 plutony wzmocnionej 2 kompanii 51 pp wyruszyły z pozycji wy jściowych na skraju lasu i pod osłoną ciemności, unikając otwarcia ognia, przekroczyły wolną przestrzeń na południe od fortu, osiągając przebiegającą tamtędy drogę. Podejście do fortu ułatwiała zalegająca przygruntowa mgła. Na przedzie posuwali się żołnierze plutonu pionierów, mający wykonać przejścia $\mathrm{w}$ napotkanych zaporach przeciwpiechotnych. Za najdogodniejszy punkt do sforsowania zapór drutowych, a następnie rowu wodnego uznany został narożnik w lewym (południowym) barku fortu, naprzeciw wysadzonej i rozebranej półkaponiery barkowej. Część pionierów zajęła pozycje w rowach przydrożnych, pozostali ruszyli w kierunku fosy fortu, wycinając przejście w napotkanych zaporach drutowych.

„Dookoła głęboka cisza. Tu i ówdzie przytłumione klapnięcia manierek i masek przeciwgazowych. Pluton zbliża się coraz bardziej do fortu" - wspominał dowódca plutonu pionierów Leutnant Kroll. - „Przed plutonem dwie wysokie zapory z drutu w ponad siedmiometrowym odstępie. Dowódca plutonu daje znak obu swoim gońcom. Jeden $z$ nich ma nożyce do drutu. Obie zapory zostają szybko przecięte. Dowódca plutonu jest ze swymi obu gońcami na terenie fortu, śledzą nieprzyjacielską obsadę. Wszystko wydaje się być wolne od przeciwnika. Rozkaz od kierującego natarciem Oberleutnanta s. 18 . 
Steinhardta, dowódcy 2 kompanii pułku piechoty: Leutnant pionierów z powrotem! Przeczołgał się z powrotem przez obie zapory drutowe. Skok i jest w rowie przydrożnym" ${ }^{16}$. W międzyczasie do pozycji zajętych przez pionierów dotarł, mający wraz z nimi nacierać, 1 pluton 2 kompanii 51 pp. Jego dowódca Feldwebel Hahn omówił z Leutnantem Krollem szczegóły ataku, po czym piechurzy przystąpili do wykonywania kolejnych przejść w zaporach drutowych. Dowódca plutonu pionierów relacjonował: "Nadal całkowita cisza. Piechurzy są już w luce drugiej zapory drutowej. Leutnant pionierów wraz dowódcą jednej z drużyn jest tam również. Nagle wystrzał. To dla Polaków rozkaz otwarcia ognia. Zaczyna się gwałtowny ogień z broni maszynowej i karabinów. Cały teren fortu jest zajęty przez przeciwnika. Polak z zimną krwią czekał, aż Leutnant pionierów ze swymi gońcami podejdzie na najbliższą odległość; tylko szczęśliwemu przypadkowi należy przypisać, że ci trzej powrócili z rozpoznania. Ogień z obu stron staje się coraz bardziej silny. Polacy mają przewagę liczebną, są znakomicie zamaskowani i osłonięci. Ledwo ich widać. Pluton piechoty ma ciężkie straty. Polak w tym miejscu dokładnie się wstrzelał" ${ }^{17}$. Moment ten opisał również korespondent wojenny Albert Benary: „Jest jeszcze ciemno, kiedy Feldwebel Hahn z 2 kompanii i Leutnant Kroll od pionierów podkradają się do zapór drutowych. Ich ludzie niosą drabiny, przy pomocy których zamierzają pokonać rów fortu. Ale ledwo zazgrzytały ich nożyce na drucie, kiedy ze wszystkich stron, z okopów strzeleckich, ze stoku fortu, z okien sąsiednich domów, zabłysnął ogien" 18 .

W chwili otwarcia ognia przez czuwającą, jak się okazało, załogę fortu, przygotowani do szturmu żołnierze niemieccy znajdowali się w wyjątkowo niekorzystnym położeniu. Oba plutony - pionierów i piechoty - zdążyły już zająć stanowiska na wyeksponowanej w stronę przeciwnika skarpie przedstoku w południowo-zachodnim narożniku fortu. Przed sobą miały szeroki rów wodny, natomiast za plecami dwie zapory przeciwpiechotne $z$ wyciętymi wąskimi przejściami. Zaskoczenie gwałtownym ogniem broni maszynowej i brak możliwości natychmiastowego ukrycia się spowodowały w tej sytuacji znaczne straty. Na skraju rowu fortu został śmiertelnie ranny dowódca plutonu piechoty Feldwebel Hahn. Sanitariusz - Unteroffizier Ulbig, a także do-

16 Kroll, Erstürmung des Forts II nordwestlich Warschau durch Infanterie und Pioniere, w: Pioniere im Kampf. Erlebnisberichte aus dem Polenfeldzuge 1939, Berlin 1942, s. 68 .

17 Ibidem, s. 69.

18 A. Benary, Infanteriesturm durch Polen, Berlin 1940, s. 47. 
wódcy drużyn: Unteroffizier Niederstrasser oraz Unteroffizier Popp ruszyli mu z pomocą. Niederstrasser i Ulbig natychmiast polegli, wycofać zdołał się tylko Popp. W międzyczasie Feldwebel Hahn został jeszcze kilkakrotnie trafiony i zmarł z wykrwawienia. W przeciągu kilku minut poległo lub zostało rannych kilkunastu żołnierzy plutonu piechoty, straty miał również pluton pionierów - poległ m.in. Unteroffizier Haschke. Reszta żołnierzy obu plutonów w panice przeczołgała się przez przejścia w obu zaporach, szukając schronienia w pobliskich rowach przydrożnych ${ }^{19}$.

Pomimo utraty atutu zaskoczenia dowódca I batalionu 51 pp Oberstleutnant A. Hemman zdecydował się na kontynuowanie natarcia, licząc na możliwość osiągnięcia powodzenia przez pozostałe pododdziały kompanii Oberleutnanta D. Steinhardta. Do akcji wkroczył kolejny pluton 2 kompanii (d-ca Oberfeldwebel Johannes Miicke), osiągając zgodnie z planem teren na południowy-wschód od fortu. Pluton zdołał przedrzeć się pod ogniem przez przestrzeń pomiędzy rowem fortu a pobliskimi zabudowaniami, pokonując w dwóch miejscach pojedynczą zaporę z drutu kolczastego. W pobliżu szyi fortu żołnierze Oberfeldwebla J. Mücke starli się z grupą żołnierzy polskich, usiłujących wydostać się z odciętego fortu. Po odparciu Polaków pluton zaległ pod silnym ogniem broni maszynowej, zarówno $\mathrm{z}$ terenu fortu, jak i okolicznych zabudowań. Równocześnie, jako wsparcie plutonu Oberfeldwebla J. Mücke, do działań wszedł kolejny pluton 2 kompanii (d-ca Leutnant Nicht), z zadaniem oczyszczenia zabudowań położonych na zapolu fortu. Pomimo wsparcia artylerii i plutonu broni ciężkiej z 4 kompanii (d-ca Oberleutnant Graf Henkel von Donnersmarck), pluton Leutnanta Nichta osiągnął zaledwie południowy skraj zabudowań i zaległ, dostając się pod silny ogień z kierunku osiedla. Niedługo potem dotarł tam i również zaległ pluton broni maszynowej 4 kompanii, którego dowódca Leutnant Graf Henckel von Donnersmarck został ciężko ranny ${ }^{20}$.

Porażka natarcia I batalionu 51 pp na Fort II stała się faktem. Swoje zadanie wykonała jedynie nacierająca na lewym skrzydle 3 kompania Leutnanta Hildebrandta. Jej poszczególne plutony sforsowały zapory drutowe na północ od fortu i dostały się pod silny ogień z samego dzieła, otaczających je zabudowań i zarośli a także z kościoła w Wawrzyszewie Starym. Towarzysząca kompanii drużyna granatnika otworzyła ogień na fort, co pozwo-

19 18. Division Ia, Bericht über die Erstürmung des Fort II..., s. 65; H. Nolte, op. cit., s. 18 ,

20 18. Division Ia, Bericht über die Erstürmung des Fort II..., s. 64; H. Nolte, op. cit., s. 18 . 
liło plutonom piechoty wznowić natarcie i osiągnąć cel ataku - rozwidlenie dróg w odległości $1 \mathrm{~km}$ od wsi Gać. Prawoskrzydłowy pluton 3 kompanii zdołał dotrzeć do dwurzędowej przeszkody z drutu kolczastego na przedstoku prawego (północnego) barku fortu, gdzie zaległ pod ogniem załogi dzieła.

Sukces 3 kompanii nie znalazł jednak przełożenia na krytyczną sytuacje 2 kompanii Oberleutnanta D. Steinhardta. Żadnemu $z$ jej plutonów nie udało się wedrzeć na teren fortu, wszystkie zostały związane walką i zaległy pod silnym ogniem, ponosząc kolejne straty. W najtrudniejszej sytuacji znajdował się zdziesiątkowany ogniem polskiej broni maszynowej pluton poległego Feldwebla Hahna. Po śmierci ostatniego ze starszych podoficerów, Feldwebla Fuchsa, pozbawiony dowodzenia i rozbity pododdział został całkowicie rozproszony, tracąc jakąkolwiek wartość bojową. Przeciwko Niemcom zwrócił się również ich początkowy atut - gęsta przyziemna mgła, która kryjącym się w rowach i czołgającym żołnierzom utrudniała obserwację i prowadzenie ognia. Wobec krytycznej sytuacji dowódca 2 kompanii Oberleutnant D. Steinhardt uznał, iż własnymi siłami nie zdoła wykonać zadania i poprzez łączników poprosił dowództwo batalionu o wsparcie.

Na polecenie Oberstleutnanta A. Hemmanna $z$ pomocą ruszyła stanowiąca dotąd odwód 1 kompania (d-ca Leutnant Suckert), szybko i bez strat pokonując, pod osłoną własnej broni maszynowej, otwartą przestrzeń na południe od fortu. Nacierająca kompania dostała się jednak pod ogień broni maszynowej z dzieła i zabudowań. Leutnant Suckert został ranny, zaś silny ogień definitywnie zablokował dalsze posuwanie się pododdziału naprzód.

Wyjście $z$ patowej sytuacji próbował znaleźć dowódca plutonu pionierów Leutnant Kroll: „Dowódca plutonu pionierów podejmuje nową decyzję. O brzasku rozpoznaje na południowo-wschodnim narożniku bramę i drogę, domyślając się, że jest tam przez okop przerzucony most. Stamtąd zamierza wrócić do rowu przydrożnego i wraz ze swoim plutonem zrobić wypad wzdłuż drogi i zapór drutowych, na tyły przeciwnika i szyję fortu. Skok do rowu. Leutnant pionierów na przedzie, pionierzy tuż za nim. Polacy strzelają ze wszystkich luf, zaczyna się też ogień moździerzy. Pociski gwiżdżą nad posuwającymi się rowem naprzód pionierami. Stanowiska Polaków są rozpoznane. Gnieżdżą się oni w dobrze rozbudowanych dołach strzeleckich, oddalonych o 10 do $20 \mathrm{~m}$ od drogi" ${ }^{21}$. Pionierzy zdołali sforsować zapory dru-

21 Kroll, op. cit., s. 69-70. 
towe w pobliżu południowo-wschodniego narożnika fortu i na rozkaz Oberleutnanta D. Steinhardta, wraz z drużynami piechoty 2 kompanii, przypuścili atak na most. Gwałtowny ogień broni maszynowej uniemożliwił jednak sforsowanie rowu wodnego, zaś pluton pionierów ze stratami musiał wycofać się na ulicę.

Plutony piechoty 1 i 2 kompanii zdołały w końcu, po walkach wręcz, oczyścić część zabudowań i o godzinie 8.30 zbliżyć się do południowego skraju rowu wodnego. Na rozkaz Oberstleutnanta A. Hemmanna do akcji wkroczyła wówczas 10 kompania 51 pp (d-ca Leutnant J. Stolz). Kompania zdołała bez strat pokonać otwartą przestrzeń na południe od fortu, sforsować zapory drutowe przejściami wykonanymi wcześniej przez pluton pionierów i wzdłuż południowego skraju rowu wodnego dotrzeć do południowo-wschodniego narożnika fortu. Podejście 10 kompanii ułatwili pionierzy Leutnanta Krolla, zadymiając przedstok szyi fortu za pomocą świec.

Błyskawiczne natarcie 10 kompanii zaskoczyło grupę żołnierzy polskich, zajmujących stanowiska w zaroślach na zapolu fortu. Nacierający na czele kompanii Leutnant J. Stolz rozbroił obsługę ulokowanej tam polskiej armaty przeciwpancernej: „Z pistoletem w ręku spada na obsługę: „Ręce do góry! « Żółtobrunatni, trzęsąc się, słuchają rozkazu. Przytrzymuje celowniczemu pistolet przed nosem i rozkazuje przez niemożliwe do niezrozumienia znaki: »Pokazuj mi, jak się obsługuje twoje działo! «. Polak kręci pokrętłami. Leutnant uważnie śledzi każdy jego ruch. Następnie odsuwa go na bok: „Wiem już dosyć!«. Ludzie jego plutonu wskakują jako ładowniczy i amunicyjni kanonierzy, chwytają koła, obracają armatę przeciwpancerną w stronę mostu. Leutnant bierze na muszkę karabin maszynowy, którego ogień z mostu chłoszcze po zaporach drutowych. Bum! Bum! Dwa strzały i leży w gruzach" - relacjonował propagandysta A. Benary ${ }^{22}$. Leutnant J. Stolz oraz pisarz kompanii Unteroffizier Scheel, z pomocą jeńców, a raczej pod ich osłoną, przetoczyli działo wzdłuż rowu wodnego do przerzuconego przez fosę mostu. Kilkoma strzałami zniszczyli obsługę polskiego karabinu maszynowego, uniemożliwiająca poruszanie się po moście. Natychmiast wykorzystali to pionierzy i żołnierze 10 kompanii, przedostając się po moście na drugą stronę rowu wodnego i opanowując wał szyjowy fortu. „Polacy w kazamatach po prawej i lewej stronie wejścia nie dają za wygraną. Ciągle znowu błyska w strzelnicach starych murów. Jednak jednego po drugim tak samo niezmordowanie wyczesze Leutnant Stolz ze swoją armatą przeciwpancerną

22 A. Benary, op. cit., s. 49. 
i karabinami maszynowymi swego plutonu. Pod taką osłoną ogniową oddziałowi szturmowemu nie jest zbyt trudno przypuścić szturm przez most, wywalić bramę wejściową i wedrzeć się do fortu. Jednak opór załogi fortu nadal nie jest ostatecznie złamany. Od pomieszczenia do pomieszczenia, od gniazda oporu do gniazda oporu, muszą atakujący wybijać resztę Polaków, aż ostatni złożą broń". Broniących się w bloku koszar żołnierzy polskich zmusił do kapitulacji ogień zdobytej armaty przeciwpancernej, prowadzony przez Leutnanta J. Stolza i Unteroffiziera Scheela. Po ostrzelaniu poszczególnych pomieszczeń koszar, w szczególności ich lewej części, w której schroniła się najliczniejsza grupa Polaków, załoga fortu skapitulowała ${ }^{23}$.

W trakcie walk doszło do groźnej sytuacji na południowo-wschodnim skraju zabudowań. Znajdował się tam tylko punkt obserwacyjny Leutnanta Schmelzera z 6 baterii 18 part., osłaniany przez drużynę piechoty z 2 kompanii $51 \mathrm{pp}$. Na zabudowania natarły polskie pododdziały $61 \mathrm{pp}$, usiłujące przyjść z pomocą plutonom odciętym w Forcie II. Niemiecki obserwator artyleryjski wywołał ogien zaporowy II dywizjonu 18 part. na zabudowania i własne stanowisko, po czym wraz z obu swymi telefonistami, włączył się do bezpośrednich walk. Gwałtowny ostrzał artyleryjski zatrzymał polski kontratak, niszcząc przy okazji część zabudowań, w tym stanowisko obserwacyjne artylerii. W tym czasie zaalarmowany Oberleutnant D. Steinhardt z częścią żołnierzy 2 kompanii 51 pp dotarł do zabudowań, wspierając odciętych artylerzystów ${ }^{24}$. Polskie pododdziały wycofały się na pozycje wyjściowe.

Po odparciu kontrataku, przez pewien czas trwało jeszcze oczyszczanie terenu dzieła. Pionierzy Leutnanta Krolla przeszukiwali wszystkie pomieszczenia w poszukiwaniu ewentualnych „niespodzianek" w postaci ukrytych przez załogę i przygotowanych do detonacji ładunków wybuchowych. W sprawozdaniu $z$ walk o fort, sporządzonym przez sztab 18 DP, znalazły się informacje o żołnierzach polskich, którzy po poddaniu się do niewoli, ponownie podejmowali próby walki.

Zgodnie $z$ raportem sztabu 18 DP Fort II został ostatecznie uznany za zdobyty i oczyszczony o godz. 9.15. Pomimo to jeszcze o godz: 9.30 Dowództwo Artylerii nr 20 złożyło w sztabie 8 Armii meldunek: „Fort II otoczony $\mathrm{z}$ obu stron, przeciwnik nadal $\mathrm{w}$ forcie" ${ }^{25}$. Zgodnie $\mathrm{z}$ raportem dowództwa

23 18. Division Ia, Bericht über die Erstürmung des Fort II..., s. 67-68.

24 H. Nolte, op. cit., s. 19; J. Engelmann, op. cit., s. 87-88.

25 AAN, MA, T-312, rolka 37, kl. 546088, Armee-Oberkommando 8, Kriegstagebuch Feldzug Polen, Eintragung 26.9.1939. 
18 DP, na jego terenie do niewoli wzięto 73 polskich żołnierzy, zdobyto armatę przeciwpancerną, karabiny maszynowe oraz znaczną ilość amunicji różnych typów. Liczbę poległych obrońców oszacowano na 55-60 żołnierzy ${ }^{26}$.

51 pp poniósł w walkach o Fort II wyjątkowo ciężkie straty. Według H. Noltego poległo 30 żołnierzy niemieckich (w tym $4 \mathrm{w}$ stopniu Unteroffiziera), zaś 36 odniosło rany ${ }^{27}$. Różniące się dane podał J. Engelmann, oceniając straty $51 \mathrm{pp}$ (wraz z podporządkowanym plutonem pionierów) na 28 poległych i 41 rannych ${ }^{28}$. Wysokie straty były skutkiem błędów popełnionych przez sztab pułku i dowództwo I batalionu już na etapie planowania wypadu na Fort II. Nieudolnie, dwukrotnie przeprowadzone rozpoznanie terenu natarcia ( $\mathrm{w}$ tym osobiście przez dowódcę I batalionu Oberstleutnanta A. Hemmana), a także zbytnie zaufanie pokładane w zeznaniach jeńców przyczyniły się do karygodnego niedocenienia zarówno liczebności, jak i siły ogniowej załogi fortu. Utrata czynnika zaskoczenia, a właściwie dopuszczenie do sytuacji, w której to atakująca kompania została zaskoczona przez czuwających obrońców, przesądziły o przekreśleniu szansy na szybkie zdobycie dzieła. Powtarzane przez Oberleutnanta D. Steinhardta kilkukrotne próby frontalnego szturmu na fort, doprowadziły z kolei do zdziesiątkowania kompanii, której rozproszone plutony zaległy w beznadziejnej sytuacji pod silnym ogniem obrony. Trudno zatem doszukać się przypisywanych później Oberleutnantowi D. Steinhardtowi talentów dowódczych.

O zdobyciu Fortu II przesądziły w zasadzie trzy czynniki. Pierwszym z nich było spóźnione i mało energiczne przeciwnatarcie polskie, zatrzymane $\mathrm{w}$ otwartym terenie ogniem zaporowym niemieckiej artylerii. Bez wątpienia rozproszone i związane walką pododdziały I batalionu $51 \mathrm{pp}$ uległyby kontratakowi, gdyby nie przytomność umysłu obserwatora artyleryjskiego, Leutnanta Schmelzera, który w desperacji wywołał ogień artyleryjski na własne stanowisko. Drugim z czynników była brawurowa akcja Leutnanta J. Stolza, któremu udało się przetoczyć przez most zdobyczną armatę przeciwpancerną, której ogień zmusił obrońców do opuszczenia koszar i kapitulacji. Nie bez znaczenia była również natychmiastowa reakcja grupy pionierów pod dowództwem Leutnanta Krolla, który wdarł się na teren fortu wraz z obsługa armaty Leutnanta J. Stolza i z miejsca przystąpił do oczyszczania terenu.

26 18. Division Ia, Bericht über die Erstürmung des Fort II..., s. 64. Leutnant Kroll liczbę wziętych do niewoli obrońców oszacował na 80. Conf. Kroll, op. cit., s. 70.

27 H. Nolte, op. cit., s. 19.

28 J. Engelmann, op. cit., s. 88. 
Bez wątpienia wszyscy trzej wspomniani oficerowie wykazali się brawurą i osobistą odwagą. Na postawie Leutnanta J. Stolza cieniem kładzie się jednak fakt sterroryzowania jeńców $z$ obsługi armaty przeciwpancernej i zmuszenia ich do przetaczania armaty na teren fortu. Być może to ten ewidentny przykład użycia „̇̇ywych tarcz" zaważył w ostatecznym efekcie na powodzeniu natarcia i zajęciu dzieła. Z tej perspektywy przedstawienie go do odznaczenia $z$ określeniem „rycerski” w nazwie wydaje się dość ironiczne. Wątpliwości budzi również zasadność wyróżnienia tak wysokim odznaczeniem Oberleutnanta D. Steinhardta - oficera, który mimo osobistej odwagi dopuścił do zdziesiątkowania własnej kompanii i w ostatecznym rozrachunku w zdobyciu Fortu II udział miał niewielki.

Istotny wydaje się przy tym fakt, iż bezpośredni przełożony Oberleutnanta D. Steinhardta, dowódca I batalionu 51 pp Obersteleutnant A. Hemman, nie podjął kroków w celu wyróżnienia podwładnego. Wnioskodawcą odznaczenia uczestników walk o Fort II orderami Krzyża Rycerskiego był Major Alfred Kuhnert, dowódca III batalionu 51 pp i bezpośredni przełożony Leutnanta J. Stolza. Dowództwo XI KA wniosek ów natychmiast zaopiniowało pozytywnie, przesyłając do sztabu 8 Armii $^{29}$. Uzyskawszy aprobatę dowódcy 8 Armii Generala der Infanterie Johannesa Blaskowitza i dowodzącego Grupą Wojsk Lądowych „Południe” Generalobersta Gerda von Rundstedta, wniosek trafił do Naczelnego Dowództwa Wehrmachtu. O przyznaniu odznaczeń obu oficerom dziennik „Völkischer Beobachter” poinformował już w numerze z 29 września 1939 r. ${ }^{30}$ Machina propagandowa ruszyła. Informacje o nadaniu nowych odznaczeń obiegły niemal całą prasę codzienną i wojskową. Osobno zrelacjonowano uroczystość wręczenia Krzyży Rycerskich w dniu 27 października 1939 r. W przygotowanym przez Ernsta Wisshaupta okolicznościowym albumie poświęconym kampanii polskiej, zbiorczy biogram i portrety Oberleutnanta D. Steihardta i Leutnanta J. Stolza znalazły się obok kilkunastu podobizn wyróżnionych generałów.

Teren walk odwiedził m.in. znany propagandysta Albert Benary, uzyskując szczegółowe relacje uczestników walk. Opis zdobycia Fortu II ukazał się w 1940 r. w zredagowanym przezeń poczytnym zbiorku reportaży wojennych. Sporo uwagi osobom Oberleutnanta D. Steinhardta i Leutnanta

29 AAN, MA, ], T-314, rolka 477, kl. 000063, Generalkommando XI. AK, Kriegstagebuch $\mathrm{Nr}$ 1, Eintragung 26.9.1939.

30 Das Ritterkreuz des Eisernen K'reuzes, „Völkischer Beobachter” z 29 września $1939 \mathrm{r}$. 
J. Stolza poświęcił dowodzący 8 Armią General der Infanterie J. Blaskowitz w sprawozdaniu Die Einnahme von Warschau ${ }^{31}$. Znaczne fragmenty owego sprawozdania zostały następnie opublikowane w 1940 r. na łamach "Leipziger Illustrierte Zeitung".

Zdarzyły się jednak również ewidentne propagandowe „wpadki”. Najlepszym przykładem jest książka innego znanego niemieckiego propagandysty Eugena Hadamovsky'ego, który w opublikowanej przez siebie książkowej relacji Blitzmarsch nach Warschau odnotował m.in. krwawo okupiony sukces żołnierzy $51 \mathrm{pp}$ w walkach o warszawskie fortyfikacje. Opis ich czynu rozpoczął od słów: „26 września o godzinie 4 rano dowódcom kompanii Oberleutnantowi Steinhardtowi i Leutnantowi Stolzowi z 51 pułku piechoty nakazano przygotowanie swych kompanii do szturmu na Fort Mokotów"32. Awansowanie Leutnanta J. Stolza na dowódcę kompanii wydaje się nieistotnym drobiazgiem, przy zakrawającym na farsę fakcie przypisania żołnierzom 51 pp zdobycia Fortu Mokotów (w rzeczywistości zdobyli oni Fort II). Bez wątpienia opis walk o fort, równie gorliwy, co nieuważny, propagandysta uzyskał z drugiej ręki, być może zaczerpnął go z opublikowanego artykułu Generalobersta J. Blaskowitza. Podobnego typu „wpadka” przydarzyła się wspomnianemu E. Wisshauptowi. W redagowanym przez siebie, bogato ilustrowanym albumie Der grosse deutsche Feldzug gegen Polen, również Wisshaupt zdobycie Fortu Mokotów przypisał Oberleutnantowi D. Steinhardtowi i Leutnantowi J. Stolzowi ${ }^{33}$. Co ciekawe, w zamieszczonym kilkadziesiąt stron dalej zbiorczym biogramie obu oficerów dzieło forteczne, które zdobyli - Fort II - zostało zidentyfikowane prawidłowo ${ }^{34}$. Należy się zatem zastanowić, czy przyczyn rozpowszechniania tego rodzaju rażących nieścisłości nie należy doszukiwać się $\mathrm{w}$ nieprawidłowo zredagowanych jeszcze podczas kampanii wrześniowej materiałach informacyjnych dla funkcjonariuszy propagandy.

Nie wszyscy uczestnicy walk o Fort II czuli się jednak uhonorowani w dostatecznym stopniu. Dowódca plutonu pionierów Leutnant Kroll oraz artylerzysta Leutnant Schmelzer otrzymali przecież „tylko" Krzyże Żelazne

31 AAN, MA, T-312, rolka 37, kl. 545280-545289, Die Einnahme von Warschau. Von Generaloberst Blaskowitz, Oberbefehlshaber der 8. Armee.

32 E. Hadamovsky, Blitzmarsch nach Warschau. Frontberichte eines politischen Soldaten, München 1941, s. 252-253.

33 E. Wisshaupt, Der grosse deutsche Feldzug gegen Polen. Eine Chronik des Krieges in Wort und Bild, Wien 1939, s. 182.

34 Ibidem, s. 324. 
I klasy. Ujście swej frustracji dał szczególnie Leutnant Kroll, publikując relację $\mathrm{z}$ walk o fort $\mathrm{w}$ tomiku wspomnień pionierów, zredagowanym i wydanym w 1940 r. przez Obersta Liere. W swej relacji, co prawda, wzmiankował on Oberleutnanta D. Steinhardta, jednak zasługę zdobycia Fortu II przypisał Leutnantowi J. Stolzowi i sobie.

Warto wspomnieć, że echa niemieckich publikacji propagandowych, sławiących zdobycie warszawskiego Fortu II, pojawiły się już po wojnie we wspomnieniach polskich uczestników kampanii wrześniowej, w szczególności obrońców Warszawy. Oficerowie polscy zetknęli się z tymi publikacjami w obozach jenieckich, do których dostarczana była oficjalna niemiecka prasa i literatura propagandowa. Wśród komentarzy zasługuje na przytoczenie opinia płk. Stanisława Roli-Arciszewskiego, zrodzona pod wpływem lektury wspominanego artykułu Generala der Infanterie J. Blaskowitza, opublikowanego w "Leipziger Illustrierte Zeitung”: „Niemcy posługują się chwytami nie znanymi wśród ludów cywilizowanych. Łatwo było przewidzieć, czego spodziewać się po takim przeciwniku, który tegoż dnia, przy zdobywaniu fortu Wawrzyszew, nie odważając się wejść samemu w ogień obrońcy, terrorem zmusza polską, wziętą do niewoli obsługę działa przeciwpancernego do podsunięcia działa od tyłu, przed samo wejście do fortu, aby rozbić bramę wejściową i obezwładnić załogę. A trzeba dodać, że ten »rycerski « wyczyn dostąpił zaszczytu opisania go w publicznym czasopiśmie i to przez samego dowódcę armii, gen. Blaskowitza!" ${ }^{35}$. Bez wątpienia płk S. Rola-Arciszewski był pierwszą osobą, która zwróciła uwagę na ów ewidentny przypadek złamania prawa wojennego i na fakt, że niemiecka prasa i literatura pisała o nim bez jakichkolwiek ogródek.

Na zakończenie należy przypomnieć, iż obaj bohaterowie walk o Fort II niezbyt długo cieszyli się swą sławą. Awansowany w międzyczasie do stopnia Oberleutnanta (1 czerwca 1940 r.), a następnie Hauptmanna (1 czerwca 1941 r.) Josef Stolz poległ już w piątym dniu operacji „Barbarossa” 24 czerwca 1941 r. jako dowódca kompanii w 38 batalionie strzelców motocyklowych ${ }^{36}$. Natomiast awansowany do stopnia Hauptmanna (1 marca 1940 r.) i wreszcie Majora (1 kwietnia 1942 r.) Dietrich Steinhardt objął stanowisko dowódcy III batalionu 51 zmot. pp. 11 kwietnia 1942 r. został

35 S. Rola-Arciszewski, Mój wrzesień 1939, w: Obrona Warszawy 1939 we wspomnieniach, pod red. M. Cieplewicza i E. Kozłowskiego, Warszawa 1984, s. 328.

36 E. Mohr, op. cit., s. 249; H. Schäfer, Der erste Ritterkreuzträger des Heeres. Am 27. Juni 1941 fiel Josef Stolz bei einem Stoßtruppunternehmen, „Der Landser-Grołband”, nr 387 , s. $65-66$. 
odznaczony Niemieckim Krzyżem w Złocie (niẹm. Deutsches Kreuz in Gold), by już następnego dnia - 12 kwietnia 1942 r. polec w rejonie miejscowości Łowat na terenie ZSRR ${ }^{37}$.

37 E. Mohr, op. cit., s. 249; H. Schäfer, Sie bleiben mir unvergessen. Persönliche Erinnerungen an bekannte Kameraden der Division (Leutnant Stolz/Hauptmann Steinhardt/Oberleutnant Schmelzer/Leutnant May), „Alte Kameraden” 1980, nr 10, s. 23. 